\title{
ЕКОНОМІЧНА ТА ІНФОРМАЦЙНА БЕЗПЕКА ДЕРЖАВИ: ПРАВОВІ АСПЕКТИ СПІВВІДНОШЕННЯ
}

Постановка проблеми. Війна РФ проти України ведеться у різних напрямах одночасно. Системне створення викликів та загроз для всіх складників національної безпеки України свідчить про «гібридність» агресії РФ. При цьому наймасштабніші акції за своєю ефективністю, особливо у тривалій перспективі, агресор здійснює в економічному секторі та інформаційному просторі. Це зумовлено з одного боку тим, що саме економічна безпека держави є основою її суверенітету, обороноздатності та політичної стабільності суспільства. 3 іншого боку, у не конвенційних війнах економічні важелі завжди виступають високоефективною та високоточною зброєю, і їх роль у таких конфліктах постійно зростає.

На сьогодні російська агресія завдає удару по економічній безпеці нашої держави: загострилася економічна криза, підвищилася тінізація економічної діяльності, значно знизився рівень інвестиційної привабливості держави, збільшилися обсяги контрабанди тощо. Виснаження української економіки агресор здійснює через торговельні та інформаційні війни, значну присутність російського капіталу у стратегічних галузях економіки України, використання ресурсозалежності та інше.

За вказаних умов актуальності набуває вироблення якісно нових підходів до забезпечення стабільності економічної системи України в умовах гібридної війни, що потребує дослідження економічної безпеки на теоретичному рівні.

Аналіз останніх досліджень та публікацій. Економічна безпека держави як юридична категорія мало досліджена у науковій літературі, що в свою чергу $є$ причиною відсутності єдиного підходу до розуміння її сутності та певних проблем у правозастосуванні. В юридичному аспекті економічну безпеку держави розглядали такі вчені: Є. Білоусов, Я. Піцур, С. Лекарь, М. Штангрет та інші.

Мета статті полягає у здійсненні теоретико-правового аналізу категорії «економічна безпека держави», розгляду їі у співвідношенні з суміжним поняттям «інформаційна безпека» .

Виклад основного матеріалу дослідження. Поняття економічної безпеки закріплено у Конституції України. Зокрема, ч. 1 ст. 17 Конституції України встановлено, що захист суверенітету і територіальної цілісності України, забезпечення її економічної та інформаційної безпеки є найважливішими функціями держави, справою всього українського народу [1]. Водночас зміст цього поняття та структура економічної безпеки держави як системи в Основному законі не розкривається. У науково-практичних коментарях ця правова категорія також не аналізується.

Разом з тим, визначення цього терміну міститься у декількох підзаконних нормативно-правових актах. Так, у Методичних рекомендаціях щодо розрахунку рівня економічної безпеки України, затверджених наказом Міністерства економічного розвитку та торгівлі від 29.10.2013 № 1277, економічна безпека визначається як 
стан національної економіки, який дає змогу зберігати стійкість до внутрішніх та зовнішніх загроз, забезпечувати високу конкурентоспроможність у світовому економічному середовищі і характеризує здатність національної економіки до сталого та збалансованого зростання [2].

Прикметно, що у Методиці розрахунку рівня економічної безпеки України, яка діяла до методичних рекомендацій від 2013 р., під економічною безпекою розумівся стан національної економіки, який дає змогу зберігати стійкість до внутрішніх та зовнішніх загроз і здатний задовольняти потреби особи, сім'ї, суспільства та держави [3]. Наведені дефініції свідчать про певний розвиток поняття економічної безпеки, який відображає зміну пріоритетів держави у цій сфері. На думку автора, закладення в основу цього поняття критерію здатності задовольняти потреби особи, сім’ї, суспільства та держави більш відповідає тим викликам та проблемам, які сьогодні існують у національній економіці.

Засадниче значення для тлумачення економічної безпеки держави має формула однойменної спеціальності, закріплена у Паспорті спеціальності 21.04.01 - економічна безпека держави (економічні науки), що затверджений Президією ВАК України від 15.12.2004 протокол № 11-10/11т. Зокрема, відповідно до розділу 1 вказаного Паспорта спеціальності, економічна безпека держави - це галузь науки, яка досліджує національні економічні інтереси та загрози економічній безпеці України, здатність держави до захисту національних економічних інтересів від зовнішніх та внутрішніх загроз, а також здатності національної економіки зберігати та поновлювати процес суспільного відтворення і достатній оборонний потенціал у кризових ситуаціях [4]. Вказане визначення побудоване на переліку об'єктів дослідження цієї галузі науки, які виступають об'єктами та напрямами системи економічної безпеки держави.

Варто також зазначити, що категорія «економічна безпека» вживається в Господарському кодексі України, але не деталізується. В цілому ж положеннями вищезазначеного кодексу доведено, що економічна безпека є основою економічної діяльності суб'єктів господарювання, які функціонують відповідно до вимог господарського законодавства. Основні норми господарського законодавства створюють достатньо міцну правову основу забезпечення економічної безпеки на мікрорівні (рівні суб'єктів господарювання) [5, с. 91].

Для розкриття сутності економічної безпеки потрібно звернутися і до міжнародно-правових джерел, оскільки цей термін увійшов у вітчизняний науковий обіг із міжнародної практики. Так, на 40-й сесії ООН 1985 р. було прийнято резолюцію «Міжнародна економічна безпека», де визначено, що економічна безпека - це такий стан, за якого народ може самостійно, без тиску ззовні і будь-якого втручання визначати шляхи й форми свого економічного розвитку.

Питання економічної безпеки знаходяться на постійному моніторингу в $\mathrm{OOH}$, зокрема аналізуються міжнародні аспекти забезпечення економічної безпеки, як основи для розвитку відносин між розвиненими країнами та країнами, що розвиваються. У цьому контексті слід згадати перші документи з цих питань: доповідь Генерального секретаря ООН «Концепція міжнародної економічної безпеки» 1987 р. та резолюція Генеральної Асамблеї ООН «Міжнародна економічна безпе- 
ка» 1987 р. У вказаних документах аналізуються національні та міжнародні джерела загроз економічній безпеці країн, що розвиваються, а також визначаються ключові проблеми світової економіки. Економічна безпека розглядається як стан економіки держави, який забезпечує здатність протистояти несприятливому зовнішньоекономічному впливу.

Наведені вище нормативні визначення економічної безпеки держави стали основою для відповідних теоретико-правових досліджень. Наприклад, автори монографії «Економічна безпека України: сутність і напрями забезпечення» В. Шлемко, I. Бенько зазначають, що економічна безпека в найбільш загальному вигляді $€$ таким станом національної економіки, який дозволяє зберігати стійкість до внутрішніх і зовнішніх загроз і здатен задовольнити потреби особи, сім'ї, суспільства, держави [6, с. 3]. Як бачимо, автори монографії повністю погоджуються з нормативним визначенням економічної безпеки, що міститься у Методиці розрахунку рівня економічної безпеки України від 2007 р.

Схожу позицію займає Г. Пухтаєвич, стверджуючи, що економічна безпека $є$ таким станом національної економіки, який дає, забезпечує можливість захисту інтересів на національному рівні, відповідний рівень стійкості до зовнішніх та внутрішніх загроз, здатність розвивати та захищати життєво-важливі інтереси громадян, суспільства, країни [7]. В юридичній енциклопедії економічна безпека характеризується як стан національної економіки з погляду забезпечення іï розвитку та матеріальних інтересів людей. Такий стан досягається системою організаційно-правових, технологічних та інших заходів економічного характеру [8].

В. Предборський пропонує визначати сутність економічної безпеки як стан економіки й інститутів влади, за якого забезпечуються гарантований захист національних інтересів, соціальна спрямованість політики, достатній оборонний потенціал навіть за несприятливих умов розвитку внутрішніх та зовнішніх процесів [9, с. 16].

Наведені вище позиції авторів свідчать про розгляд економічної безпеки у статиці, відповідно, її зміст розкривається через категорії «стан національної економіки» та «стан інститутів влади».

Серед науковців поширеним є динамічний підхід до визначення поняття економічної безпеки держави. Так, С. Лекарь зазначає, що характеризуючи безпеку в економічному аспекті, її слід розуміти як можливість застосування ресурсів, необхідних для нормального та стабільного функціонування господарської одиниці, а також для їі економічного росту [10, с. 400].

У статті Ю. Самойленко, М. Григорчук досліджуються певні аспекти юридичної природи економічної безпеки з позицій макрорівня (рівня держави). На думку авторів, економічна безпека держави є комплексом ефективних методів та форм захисту (з одного боку) і протидії (з іншого боку) різноманітним економічним проявам недружнього характеру, які загрожують встановленому законом порядку реалізації всіма суб'єктами фінансово-господарських відносин, визначених законодавчо прав на розвиток та об'єктивне самовідтворення, збільшенню добробуту на національному рівні, повноцінному забезпеченню потреб населення країни [11].

У Концепції економічної безпеки України вона розглядається як «спроможність національної економіки отримувати свій вільний, незалежний розвиток 
і утримувати стабільність громадянського суспільства та його інститутів, а також достатній оборонний потенціал країни за всіляких несприятливих умов і варіантів розвитку подій, здатність України до захисту національних, економічних інтересів від зовнішніх і внутрішніх загроз [12, с. 4].

Досить часто у наукових працях зустрічається застосування системно-структурного підходу до розуміння економічної безпеки, який дозволяє розглядати їі як логічно-побудовану систему, елементи якої є взаємопов'язаними та взаємодіючими. Так, В. Савін вважає, що економічна безпека є системою захисту важливих інтересів країни [13, с. 14].

Н. Попадинець наголошує, що економічна безпека - це сукупність умов, що забезпечують незалежність національної економіки, їі стабільність і стійкість, здатність до постійного відновлення і самовдосконалення, здатність економіки забезпечувати ефективне задоволення ендогенних та екзогенних суспільних потреб [14, с. 21].

У правовому аспекті економічну безпеку держави можна розглядати як правовідносини, що виникають при забезпеченні органами публічної влади стану захищеності національної економічної системи.

Схожий підхід при дослідженні економічної безпеки держави використовують і вчені-економісти. Наприклад, I. Мішина пропонує розглядати економічну безпеку як систему економічних відносин, як горизонтальних, так і вертикальних, між державою, регіонами, фірмами та окремими індивідами з приводу досягнення такого рівня економічного розвитку, при якому забезпечується ефективне задоволення потреб і гарантований захист інтересів всіх суб'єктів економіки навіть при несприятливих умовах розвитку внутрішніх та зовнішніх процесів [15].

Економічна безпека пов'язана з іншим складником національної безпеки - інформаційною. Вивчення доктринальної основи останньої категорії засвідчує різні підходи до розуміння природи і сутності інформаційної безпеки, насамперед у юридичній науці та інших галузях вітчизняної науки. Слід підкреслити термінологічну невизначеність, неоднозначність та авторське бачення цієї категорії.

Так, в узагальненому вигляді інформаційну безпеку автором було визначено крізь призму правовідносин, що виникають при забезпеченні стану захищеності інформаційного простору. Обгрунтованим є комплексне трактування сутності та гарантій забезпечення інформаційної безпеки держави як напряму державної політики у сфері національної безпеки і оборони, невід’ємної частини політичного, економічного, оборонного та інших складників національної безпеки. Це підтверджується аналізом положень Конституції України, Законів України «Про національну безпеку України», «Про Концепцію Національної програми інформатизації», «Про Основні засади розвитку інформаційного суспільства в Україні на 2007-2015 роки», «Про оборону України». У всіх випадках інформаційна безпека визнається одним із напрямів державної політики у сфері національної безпеки і оборони [16-19].

Хоча економічна безпека та інформаційна безпека різняться за об'єктом (економічна система, інформаційний простір) та засобами забезпечення, проте мають і спільні риси. Так, йдеться про низку таких характерних ознак: 
1) є складниками національної безпеки;

2) їх забезпечення є найважливішою функцією держави;

3) їх регулювання має правову основу;

4) мають однакові рівні забезпечення (міжнародний, національний та локальний) ;

5) схожими фактично є їх суб'єкти - держави (відповідні органи і посадові особи, міжнародні організації, громадяни тощо). Їх першочерговими цілями виступають попередження та усунення загроз, захист суверенітету держави у визначених cфpepax.

Висновки. На підставі вищевикладеного, можна зробити висновок про те, що економічна та інформаційна безпеки є конституційними категоріями, хоча зміст їх в Основному законі не розкривається. Аналіз наукових досліджень свідчить про застосування різних підходів до з'ясування сутності економічної безпеки держави. При цьому, найпоширенішими серед авторів є статичний, динамічний, системно-структурний та комплексний підходи. Єдине нормативне визначення економічноїбезпеки, що міститься унаказі Міністерстваекономічного розвиткута торгівлівід 2013 р., засноване саме на статичному підході. В юридичній площині економічну безпеку держави можна розглядати як правовідносини, що виникають при забезпеченні органами публічної влади стану захищеності національної економічної системи.

\section{Jimepamypa}

1. Конституція України від 28.06.1996 № 254к/96-ВР. Відомості Верховної Ради України. 1996. № 30. Ст. 141.

2. Про затвердження Методичних рекомендацій щодо розрахунку рівня економічної безпеки України: Наказ Міністерства економічного розвитку та торгівлі від 29.10.2013 р. № 1277. URL: https://zakon.rada.gov.ua/rada/show/v1277731-13.

3. Про затвердження Методики розрахунку рівня економічної безпеки України: Наказ Міністерства економіки України від 02.03.2007 р. № 60. URL: https://zakon.rada.gov.ua/rada/show/ v006066507/ed20070302/find?Text $=\%$ C5 $\%$ EA $\%$ EE $\%$ ED $\%$ EE $\%$ EC $\%$ B3 $\%$ F7 $\%$ ED $\%$ E0 $+\%$ E1 $\%$ E5 $\%$ $\mathrm{E} 7 \% \mathrm{EF} \% \mathrm{E} 5 \% \mathrm{EA} \% \mathrm{E} 0$.

4. Паспорт спеціальності 21.04.01 - економічна безпека держави (економічні науки): Президія ВАК України від 15.12.2004 протокол № 11-10/11т. URL: https://zakon.rada.gov.ua/rada/show/ va11-33004/ed20041215/find ?text=\% E5\% EA \% EE\% ED \% EE \% EC \% B3\% F7\% ED \% B3.

5. Білоусов Є.М. Юридична природа економічної безпеки як категорії господарського права. Європейські перспективи. № 12. 2013. С. 88-93.

6. Шлемко В.Т., Бінько І.Ф. Економічна безпека України: сутність і напрями забезпечення : монографія. Київ : НІСД, 1997. 144 с.

7. Пухтаєвич Г.О. Аналіз національної економіки : навч. посіб. Київ : КНЕУ, 2005. $254 \mathrm{c}$.

8. Юридична енциклопедія: В 6 т. / Редкол.: Ю.С. Шемшученко (відп. ред.) та ін. Київ : Укр. енциклопедія, 1998. 1999. Т. 2.: Д-Й. 744 с.

9. Предборський В.А. Економічна безпека держави : монографія. Київ : Кондор, 2005. $391 \mathrm{c.}$

10. Лекарь С.І. Поняття та зміст економічної безпеки. Форум права. 2012. № 2. С. 399-402.

11. Самойленко Ю. Економічна безпека України: правовий аспект. URL: http://www.viche.info/ journal $/ 3838 /$.

12. Гаєць В.М., Кваснюк Б.Є. та інші. Концепція економічної безпеки України. Київ : Логос, 1999. $56 \mathrm{c}$.

13. Савин В.А. Некоторые аспекты экономической безопасности России. Международный бизнес России. 1995. № 9.

14. Попадинець Н.М. Основні чинники забезпечення економічної безпеки України. Соціально-економічні проблеми сучасного періоду України. 2016. № 2. С. 20-23. 
15. Фоміна М.В., Мішина І.Г. Глобальна економічна безпека: сутність і тенденції. URL: http://trade.donduet.edu.ua/download/2011/32/Fom_Mish.pdf.

16. Шемчук В.В. Інформаційна безпека та інформаційна оборона у контексті розвитку вітчизняної доктрини і законодавчої основи. Вісник Таврійського національного університету ім. В.І. Вернадського. Серія юрид. науки. 2019. № 4.

17. Камінська Н.В. Перспективи гармонізації законодавства України в умовах інтеграції в європейський інформаційний простір. Європейська інтеграція України: сучасний стан та перспективи розвитку, тези підсумкової наук.-теорет. конф. (Київ, 22 квіт. 2016 р.). К., 2016. С. 33-35.

18. Про Основні засади розвитку інформаційного суспільства в Україні на 2007-2015 роки: Закон України від 09.01.2007 № 537-V. Відомості Верховної Ради України, 2007, № 12, ст. 102. URL: http://zakon2.rada.gov.ua/laws/show/537-16.

19. Петрик В. Сутність інформаційної безпеки держави, суспільства та особи. Юридичний журнал. 2009. № 5. С. 122-134.

20. Забезпечення інформаційної безпеки держави : підручник / за заг. ред. О.А. Семченка та В.М. Петрика. Київ : ДНУ «Книжкова палата України», 2015. 672 с.

\section{Анотація}

Шемчук В. В. Економічна та інформаційна безпека держави: правові аспекти співвідношення. Стаття.

Стаття присвячена дослідженню економічної та інформаційної безпеки держави, їх теоретико-правовим, конституційно-правовим та іншим галузевим і прикладним аспектам. Проаналізовані нормативні визначення категорії «економічна безпека держави», висвітлена історія виникнення і розвитку цього терміну у міжнародно-правовій практиці.

Так само як і інформаційна безпека, економічна безпека є конституційною категорією, хоча зміст їх в Основному законі не розкривається. Аналіз наукових досліджень свідчить про використання різних підходів до з'ясування сутності економічної безпеки держави. (найбільш поширеними є статичний, динамічний, системно-структурний та комплексний підходи). Єдине їі нормативне визначення регламентовано у наказі Міністерства економічного розвитку та торгівлі 2013 р., засноване саме на статичному підході. В юридичній площині економічну безпеку держави можна розглядати як правовідносини, що виникають при забезпеченні органами публічної влади стану захищеності національної економічної системи.

Суміжним поняттям поряд з економічною безпекою держави є інформаційна безпека країни. Останню доцільно розглядати крізь призму правовідносин, що виникають при забезпеченні стану захищеності інформаційного простору.

Економічна та інформаційна безпеки різняться за об'єктом (економічна система, інформаційний простір) та засобами забезпечення. Проте, вони мають і спільні риси: йдеться про одночасне визначення складниками національної безпеки; їх забезпечення є найважливішою функцією держави; однакові рівні забезпечення (міжнародний, національний та локальний); схожі суб’єкти тощо.

Економічна безпека держави, як і інформаційна безпека стали предметом вивчення різних галузей вітчизняної науки, включаючи насамперед юридичну науку. Отже, на сьогодні сформувалась їх належна доктринальна основа, проте беззаперечною є потреба вдосконалення нормативно-правової бази у сфері економічної та інформаційної безпек як складників національної безпеки України, забезпечення термінологічної визначеності, механізмів реалізації, гарантій захисту як у мирний час, так $\mathrm{i}$ в умовах конфліктів, гібридних воєн тощо.

Ключові слова: економічна безпека, інформаційна безпека, гібридна війна, держава, стан економіки, ООН.

\section{Summary}

Shemchuk $V . V$. Economic and information security of the state: legal aspects of relationship. Article.

The article is devoted to the study of the economic and information security of the state, their theoretical and legal aspects. The normative definitions of category "economic security of the state" are analyzed. Thus, the concept of economic security is enshrined in the Constitution of Ukraine. In particular, part 1 of Article 17 of the Constitution of Ukraine establishes that the protection of the sovereignty and territorial integrity of Ukraine, ensuring its economic and information security are the most important functions of the state, the cause of the entire Ukrainian people. At the same time, the meaning of this concept and the structure of economic security of the state as a system are not disclosed in the Basic Law. This legal category is also not analyzed in scientific and practical commentary. However, the definition of this term is 
contained in several by-laws, the main of which is the Methodological Recommendations for the calculation of the level of economic security of Ukraine of 2013.

In order to reveal the essence of economic security, one should also refer to international legal sources, since this term has entered into domestic scientific circulation from international practice. In particular, the 40th session of the UN in 1985 adopted a resolution "International Economic Security", which determined that economic security is a condition in which the people can independently, without pressure from outside and any intervention, determine the ways and forms its economic development. Economic security issues are constantly monitored at the UN in particular the international aspects of economic security are being analyzed as a basis for developing relations between developed and developing countries.

In legal encyclopedia economic security is characterized as a state of the national economy in terms of ensuring its development and material interests of people. Such a state is achieved by a system of organizational, legal, technological and other measures of an economic nature.

The analysis of scientific works shows that different approaches are used to find out the essence of economic security of the state. In this case, the most common among the authors are static, dynamic, system-structural and integrated approaches. In the legal plane, the economic security of the state can be regarded as a legal relationship that arises when the public authorities provide the state of protection of the national economic system.

Economic security is linked to another component of national security, such as information security. And although they differ in object (economic system, information space) and means of security, they also share the following common features: they are national security components; their supporting is an essential function of the state; their regulation has a legal basis; have the same levels (international, states and individuals) and subjects; and serve as the primary targets in hybrid wars.

Key words: economic security, information security, hybrid war, state, economy, UN. 